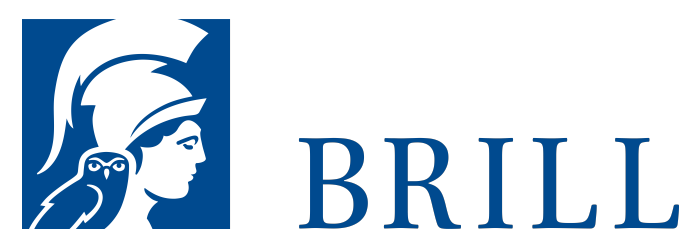

\title{
The Commentary of Pappus on Book X of Euclid's Elements
}

Authors: William Thomson and Gustav Junge

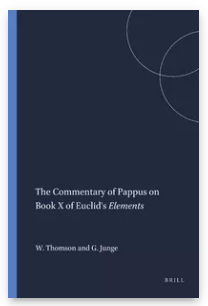

Language:

English

Subjects:

Philosophy,

Science \&

Medicine,

Ancient Near

East and Egypt,

Mathematics \&

Computer

Sciences,

Biology

Publisher: Brill

Series:

Harvard Semitic Studies, Volume: 8

E-Book (PDF)

Released online: 25 Feb 2020

ISBN: $978-90-$

04-38440-8

List price

USD $\$ 66.00$

Paperback

Publication date:

o1 Jan 1930

ISBN: 978-90-

04-41155-5

List price

USD $\$ 66.00$ 
For more information see brill.com

Order information: Order online at brill.com +44330 333 0049 | customerservices@brill.com Submission information: brill.com/authors

Titles published by Brill | Fink, Brill | mentis or Brill | Schöningh: +49(o)715413279216| brill@brocom.de 